\title{
The Effectiveness of Antitrust Collective Litigation in the European Union: A Study of the Principle of Full Compensation
}

\author{
Žygimantas Juška
}

Published online: 27 November 2017

(C) The Author(s) 2017. This article is an open access publication

\begin{abstract}
Policy preferences in the US shape private antitrust remedies in the form of deterrence; any compensation failures can be justified as long as the deterrent function is successful. In contrast, EU private antitrust enforcement seeks to ensure that anyone who has suffered harm from a violation of competition law can effectively exercise their right to claim full compensation; deterrence can be seen as a mere side effect. This paper will demonstrate that full compensation is unfeasible in practice, because compensating direct purchasers and indirect purchasers will inevitably fail to a greater or lesser degree. Second, it will show that the EU's compensation-based mechanism, with a specific emphasis on full compensation, has more of a need for deterrence-based tools than the deterrence-focused mechanism of the US.
\end{abstract}

Keywords Full compensation · Deterrence $\cdot$ Private enforcement · Damages actions · Direct purchasers $\cdot$ Indirect purchasers

\section{Introduction}

Traditionally, the enforcement of the competition law system of the European Union has been the exclusive competence of the EU's public enforcer - the European Commission. However, after the adoption of Council Regulation 1/2003, the national competition authorities (NCAs) and national courts were empowered to

The author was an EU Fulbright Schuman grantee at Stanford University and the University of Michigan (2015-2016). This article is based on a study performed in the US.

\section{Ž. Juška (凹)}

PhD candidate, Leiden Law School, Leiden University, Leiden, The Netherlands

e-mail: z.juska@umail.leidenuniv.nl 
enforce EU antitrust rules alongside the Commission. ${ }^{1}$ Time has shown that Member States have successfully enforced EU competition rules in the national context. ${ }^{2}$ Therefore, public enforcement has reached a point of stability and maturity over the last decade. In contrast, private enforcement is underdeveloped in compensating consumers and SME's, especially if they are indirect purchasers. Due to the ineffective right to claim damages, victims are losing billions of euros per year. ${ }^{3}$ However, it is true that several direct purchaser actions have been brought in EU Member States, yet the disputes have mainly been between large corporations.

The ineffectiveness of the private antitrust enforcement regime has created more incentives for the European Commission to enhance damages actions. The search for an appropriate system of private antitrust enforcement has culminated in the adoption of the Directive on antitrust damages actions ${ }^{4}$ and the Recommendation on collective redress mechanisms. ${ }^{5}$ Although the Recommendation takes the form of a horizontal framework (across all legal fields), its relevance for competition law is particularly highlighted by the fact that it was adopted simultaneously with the Proposal for a Directive on damages actions. For the purposes of this study, the latter package, consisting of the Directive and the Recommendation, is called the EU private antitrust reform.

The reform is focused on the objective of compensation, while deterrence can be seen as only a side effect. The Directive requires all EU Member States to ensure that anyone who has suffered harm due to an infringement of competition law can effectively exercise their right to claim full compensation. ${ }^{6}$ This means that each financial victim down the supply chain, including the end consumer, is entitled to actual loss, loss of profit plus interest. This paper will discuss to what extent the EU private antitrust reform is capable of achieving the objectives of full compensation.

The EU's compensation approach stands in contrast with that of the United States, where antitrust policy preferences shape private remedies in the form of deterrence. Indeed, the availability of deterrence-oriented remedies incentivized the development of the so-called "private attorney general", i.e. a lawyer who enforces the laws so aggressively that private remedies have become a motivating power in antitrust enforcement. ${ }^{7}$

Specifically, the following questions will be answered in this paper:

\footnotetext{
${ }^{1}$ Council Regulation No 1/2003 of 16 December 2002 on the implementation of the rules on competition laid down in Articles 81 and 82 of the Treaty [2004] OJ L 1/1.

2 NCA's reported that there were 1334 investigations and 646 envisaged final decisions between 1 May 2004 and 31 December 2012. For the further discussion, see Wils (2013), pp. 295-296.

${ }^{3}$ Renda et al. (2008), p. 11.

${ }^{4}$ Directive 2014/104/EU of the European Parliament and of the Council of 26 November 2014 on certain rules governing actions for damages under national law for infringements of the competition law provisions of the Member States and of the European Union [2014] OJ L349.

${ }^{5}$ Commission Recommendation of 11 June 2013 on common principles for collective redress mechanisms in the Member States for injunctions against and claims on damages caused by violations of EU rights $\operatorname{COM}(2013) 3539 / 3$.

${ }^{6}$ Directive, supra note 4, Arts. 1, 3 .

${ }^{7}$ Over $90 \%$ of antitrust litigation is filed by private plaintiffs. See, for example, Sourcebook of Criminal Justice Statistics Online (2004).
} 
1. To what extent can the EU private antitrust reform achieve the objective of full compensation?

2. Can EU compensatory collective actions survive without deterrence-based measures?

The following steps will be taken to address these questions. First, the impact of the indirect purchaser rule on full compensation will be discussed. Second, the role of antitrust collective actions in fulfilling the objective of fully compensating victims will be analysed. Third, the necessity of US deterrence-based remedies in the EU's compensation-oriented system will be debated.

Following the introduction, Sect. 2 gives an overview of the basic definitions and objectives of enforcement models in EU competition law, with a particular emphasis on private enforcement. Section 3 describes the antitrust policy preferences under private remedies in the US and in the EU. Section 4 assesses how the key provisions of the EU private antitrust reform interact with the principle of full compensation. Section 5 analyses the impact of deterrence-based remedies in the EU compensatory collective actions.

\section{The Role of Private Enforcement in the Competition Law of the European Union}

\subsection{A General Background of the Enforcement of EU Competition Law}

The EU's main competition rules are set out in Arts. 101 and 102 in the Treaty on the Functioning of the European Union (TFEU). ${ }^{8}$ Article 101 prohibits agreements or concerted practices between two or more undertakings which have the objective of preventing, restricting or distorting competition within the internal market. Article 102 prohibits the abuse of a dominant position by one or more undertakings in a particular market within the EU, insofar as it distorts trade between Member States. In general, the enforcement of competition law primarily seeks to remedy anti-competitive situations. This is to be achieved by pursuing the following three objectives through two models of enforcement: public and private enforcement.

\subsubsection{Identify the Violation and Clarify the Surrounding Legal Situation}

This objective has been pursued mainly through public enforcement, which operates within a two-tiered system: the European Commission's DG Competition at the EU level, and the NCAs at the national level. Private enforcers are motivated by private gains and hence mainly pick up low-risk cases, while, competition authorities have better investigatory tools and are able to coordinate their activities with other public authorities.

\footnotetext{
${ }^{8}$ Consolidated Version of the Treaty on European Union [2008] OJ C115/13.
} 


\subsubsection{Punish the Perpetrator and Deter from Breaching the Law in the Future}

The deterrent function is pursued through the imposition of competition fines, which punish the infringer (in other words, specific deterrence). It also deters other persons from engaging in or continuing behaviour contrary to competition rules (in other words, general deterrence). ${ }^{9}$ According to the EU, public enforcement is considered to have sufficient means for achieving deterrence. ${ }^{10}$ In this respect, it must be borne in mind that EU competition law focuses exclusively on imposing fines on infringing businesses, but Member States are given space to introduce other types of penalties. ${ }^{11}$ In order to combat cartels, a majority of EU Member States have incorporated criminal sanctions on individuals (such as imprisonment or criminal fines) in their antitrust enforcement schemes. ${ }^{12}$ However, these sanctions have very rarely been imposed in practice. ${ }^{13}$ Therefore, public authorities in the EU jurisdictions have failed in setting an example for criminal penalties being effectively utilized in public enforcement.

\subsubsection{Achieve Corrective Justice When the Infringement Has Taken Place}

This goal can be pursued if two conditions are met. ${ }^{14}$ First, corrective justice is achieved if the monetary remedy deprives the wrongdoer of any benefit gained from illegal conduct. This measure may be used when public enforcers impose a suboptimal fine. As such, the enforcement may be reinforced by imposing additional fines on the wrongdoer in order to fully remedy the anti-competitive situation. Second, corrective justice is achieved when victims are compensated for the harm suffered. According to the Directive on damages actions, the objective of compensation is fulfilled when victims effectively exercise the right to claim and to obtain full compensation for the harm suffered. However, this objective should not lead to overcompensation of the claimants, whether by means of punitive, multiple or other kinds of damages. ${ }^{15}$ For this reason, the enforcement of the first condition may not comply with the principle of full compensation, as additional fines (besides damages on fully compensating victims) may be required to ensure corrective justice. As a consequence, only the second condition will be further discussed in this paper.

The enforcement of full compensation is primarily realized through private enforcement. Antitrust victims may bring a claim for damages or for injunctive

\footnotetext{
9 For the discussion on both types of deterrence, see European Commission Guidelines on the method of setting fines imposed pursuant to Art. 23(2)(a) of Regulation No 1/2003 [2006] OJ C 210/2, para. 4.

10 See, for example, Italianer (2013).

11 Regulation 1/2003 did not harmonise sanctions for antitrust violations. This is probably because the EU seeks to comply with Art. 83(2) of the TFEU, which preserves the sovereignty of the EU Member States in criminal matters. For discussion on the issue, see Günsberg (2015), pp. 55-59.

12 For the study, see Harrison and Jones (2014); Whelan (2012).

13 See, for example, Jones and Harrison, supra note 12; Slotboom (2013).

14 For the additional discussion, see Wils (2009), p. 3.

15 Directive, supra note 4, Art. 3.
} 
relief. ${ }^{16}$ However, claims for damages are more attractive, as financial benefits are expected. In contrast, injunctions only aim to cease the violations of victims' rights granted by EU law. The antitrust claim may be brought on a stand-alone basis or on a follow-on basis. The former action is popular in the United Kingdom, while the latter is predominant in civil law countries. ${ }^{17}$

To sum up, the EU seeks to create an effective system of private enforcement that "complements, but does not replace or jeopardise, public enforcement". ${ }^{18}$ However, it is true that effective private enforcement, allowing for a multitude of victims to obtain compensation, can also serve a deterrence function. ${ }^{19}$ The basic idea is that if more victims are compensated (especially if these claims would not otherwise be litigated), there are broader possibilities to force the wrongdoers to internalize the negative effects of the damage caused. Therefore, successful compensatory actions may deter potential wrongdoers. Until now, however, private enforcement has had little effect on compensation, and the impact on deterrence is likely absent. There are at least two reasons for this. First, the actions for damages have been mainly brought in Germany, the Netherlands and the UK. ${ }^{20}$ Second, the cartel damages claims have been mostly brought by corporations, meaning that ordinary consumers have been inactive in bringing private claims - both as a group and individually. ${ }^{21}$

In conclusion, it should be stressed that the principal aim of this paper is to analyse the role of private enforcement, and collective actions in particular, in fulfilling the objective of full compensation. Deterrence is analysed only as regards the means of enforcement of full compensation. Furthermore, the discussion on clarifying the terms of antitrust violations is disregarded in this paper.

\subsection{The Evolution of Private Antitrust Remedies}

Traditionally, the enforcement of EU competition law has mostly been carried out by the European Commission. The situation changed dramatically when the enforcement of competition law was amended by Regulation 1/2003. The key measures included, inter alia, the following: (a) stimulating national courts' activity in the enforcement of EU competition law; (b) decentralizing the enforcement of EU competition rules; and (c) strengthening the possibility for individuals to seek

\footnotetext{
16 The injunctions, for example, are allowed under the Directive 2009/22/EC of the European Parliament and of the Council of 23 April 2009 on injunctions for the protection of consumers interests [2009] OJ L 110.

17 The exception of a stand-alone case in a civil law country can be found in the Lithuanian jurisdiction. See AB flyLAL-Lithuanian Airlines v. Air Baltic Corporation A/S and Airport Riga, Decision of the Court of Appeals of Lithuania of 31 December 2008, civil case No. 2-949/2008. For the discussion on standalone actions in the UK, see Kuijpers et al. (2017), pp. 56-58.

18 White Paper on damages actions for breach of the EC antitrust rules COM (2008) 165 final, Sec. 1.2.

19 Communication from the Commission to the European Parliament, the Council, the European Economic and Social Committee and the Committee of the Regions "Towards a European Horizontal Framework for Collective Redress", COM (2013) 401/2.

${ }^{20}$ For the discussion on these jurisdictions, see Kuijpers et al., supra note 17.

21 BarentKrans (2015). In 2015, there were 65 pending cartel damages claims in Europe, but one was brought outside the EU (in Belarus). It seems that no end-consumer/citizen collective claims have been brought.
} 
redress before national courts. Thus, the aim of facilitating private enforcement was on the EU's agenda. At the same time as the EU legislators were taking the aforementioned steps, the objective to improve antitrust damages actions was reinforced by the Court of Justice of the European Union (CJEU) ruling in Courage v. Crehan. ${ }^{22}$ The Court held that private antitrust actions contribute to the effective enforcement of competition law, and hence victims should be able to claim damages for the harm suffered. ${ }^{23}$

Following the CJEU decision, the Commission aimed at identifying key barriers to the further promotion of antitrust damage actions in its policy proposals in the Green Paper $^{24}$ and the White Paper. ${ }^{25}$ Both papers recognized the need for collective redress mechanisms in the field of antitrust. While the Green Paper did not specify the types of collective actions, the White Paper suggested a combination of two complementary mechanisms of collective redress: representative actions, and opt-in collective actions. Although both papers identified problems that needed to be addressed, only in 2013 did the European Commission eventually conclude its longawaited package on antitrust damages claims. The most important step was taken in November 2014, when the EU adopted the Directive on damages actions. It is designed to remove obstacles to compensation for victims of infringements of EU competition law and to balance interests between public and private enforcement. Member States were required to implement the provisions of the Directive in their national legal systems by the end of 2016. However, countries struggled to implement the Directive into national laws: only five countries managed to accomplish this in time. ${ }^{26}$ The Directive should be strongly criticized for not including provisions on collective redress actions. These actions are the main, if not the only tool for small-stakes actions to be heard in courts, as pursuing them individually is financially unfeasible. In order to facilitate the situation, the Recommendation on collective redress was published. However, the Recommendation is not very helpful, since it is a non-binding document and does not incentivise Member States to take actions. Another viewpoint is that the Recommendation takes a horizontal approach, and as such its content applies to all areas of law. Given that the Recommendation was adopted together with the draft on the Directive, it shows a particular desire for more extensive private litigation within the area of competition law. Yet, ultimately, the reality is that no measures on collective redress were included in the Directive on competition damages.

Although DG Competition was in favour of antitrust collective litigation, it was not included in the Directive for at least three reasons. ${ }^{27}$ First, the European Commission sought to introduce a legislative instrument before the end of the mandate in 2015; only an uncontroversial proposal could pass in the European

\footnotetext{
$\overline{22}$ Case C-453/99 Courage Ltd. v. Bernard Crehan [2001] ECR I-6297.

23 Ibid, paras. 26-28.

24 Green Paper - Damages actions for breach of the EC Antitrust Rules, COM (2005) 672 final.

25 White Paper, supra note 18.

26 European Commission (2016).

27 The discussion on "three reasons" is based on the analysis of Hodges (2014), pp. 74-75.
} 
Council. The inclusion of collective redress actions, being inherently controversial due to the so-called American problems of abusive litigation, could jeopardize the very adoption of the Directive. Second, the principal aim was to clarify terms on the leniency program, especially after the CJEU decision in Pfleiderer. ${ }^{28}$ It was considered that the availability of collective actions could raise uncertainties for leniency applicants, and that they would refrain from coming forward if there was even a minimal possibility of being exposed to private claims from all victims. Third, DG Competition primarily aimed to address the technical issues on damages claims, such as limitation periods, joint and several liability, etc. Therefore, a political decision was taken to exclude collective claims, which could distort the negotiation process on technical issues.

In light of these reasons, only the Recommendation was proposed, for which a four-year trial period was given. On the basis of Member States' experiences, in 2017 it will be decided whether further legislative measures should be proposed in the field of collective redress.

\section{Policy Preferences Under Antitrust Private Actions in the United States and the European Union}

\subsection{The Deterrence-Oriented Approach in the United States}

The US Supreme Court has ruled that antitrust private actions serve two objectives: compensation and deterrence. ${ }^{29}$ But, in case of a conflict between these objectives, the Supreme Court seems to give preference to deterrence over compensation. ${ }^{30}$ The prevailing goal of deterrence is even more visible in class actions, which aggregate private actions under Rule 23 of the Federal Rules of Civil Procedure. According to the economic rationale, identifying different kinds of victims and compensating them may be financially unfeasible. ${ }^{31}$ Generally, the case costs (administrative, expertise, etc.) are substantial, hence individuals (especially consumers) obtain small individual awards. ${ }^{32}$ As such, the positive effect for the individual class member is minimal. Therefore, in the context of economic efficiency, the real and only goal of class action lawsuits, and especially of small-value claims, is to facilitate deterrence. ${ }^{33}$ In fact, with small stakes claims, which typically otherwise would not be prosecuted are aggregated, the wrongdoer is forced to better internalize the costs caused by illegal conduct. Therefore, the significantly increased number of damages claims sets the

\footnotetext{
$\overline{28}$ Case C-360/09 Pfleiderer AG v. Bundeskartellamt [2011] ECR I-05161.

29 See, for example, Am. Soc. of Mech. Eng'rs v. Hydrolevel Corp., 456 U.S. 556, 575-76 (1982); Pfizer, Inc. v. Gov.'t of India, 434 U.S. 308, 314 (1978).

30 The primary importance of deterrence was observed in Illinois Brick Co. v. Illinois, 431 U.S. 720

(1977). For further discussion, see Murray and Richman (2007), p. 90; Page (1985), p. 1452.

31 Crane (2010), pp. 682-683.

32 This is the approach of the Chicago School. See, for example, Schwartz (1980), p. 1086.

33 See, for example, Fitzpatrick (2010a), p. 2068; Friedman and Gilles (2006), pp. 105-107.
} 
example that class actions can be effectively utilized in antitrust enforcement, thereby enhancing deterrence. Indeed, class action lawsuits are mainly reinforced through a combination of five measures aimed at enhancing deterrence:

- Automatic treble damages,

- Wide-ranging discovery rules,

- An opt-out measure,

- One-way fee shifting (the absence of the "loser pays" principle),

- Lawyers being allowed to accept antitrust cases on a contingency fee basis.

Together, these measures create sufficient incentives for lawyers to enforce the antitrust laws as private attorneys general. If there was no kit of deterrence-based tools, lawyers would probably not bring antitrust cases, not only because they are difficult to detect and convict, but also considering that the total costs can be extremely high due the complexity of antitrust violations.

As regards compensation, the US experience demonstrates that class members receive low proportional awards. ${ }^{34}$ Even though victims remain highly undercompensated, the plaintiff bar receives significant compensation, which potentially overpays the class counsel. ${ }^{35}$ It should also be observed that defendants are eager to settle cases as soon as possible: the discovery proceedings may generate very high costs. ${ }^{36}$ If the case is prolonged, the discovery expenses increase proportionally. For the class counsel, it is also worth settling cases, as his or her compensation is based on the contingency fee agreement, which is calculated as a percentage of the class net recovery. However, the group is in any case large (both in number and financial capacity) due to an opt-out measure, which binds all potential victims unless someone decides to opt out.

Indeed, the objective of compensating victims is programmed to fail because most cases are settled for awards lower than actual damages. ${ }^{37}$ When case costs (administrative fees, expert fees and contingency fees) are deducted from the settlement award, it is found that class members receive low individual compensation. However, compensation is not the only objective in a deterrence-oriented system such as in the United States. The failure of compensation can be justified if the class action device facilitates deterrence. ${ }^{38}$ The basic logic is that it is better to prevent the wrongdoers from engaging in anticompetitive conduct rather than to attempt to restore

\footnotetext{
34 In automatic distribution settlements, around 35-90\% of victims receive some kind of compensation. But these victims never receive actual compensation, and their individual award is generally lower than $50 \%$ of their actual harm. On these points, see Fitzpatrick and Gilbert (2015), p. 6; Rubenstein and Pace (2008), p. 23; Hensler et al. (2000), pp. 184, 204-205, 310. In claims made settlements, only between 1 and $20 \%$ of victims receive compensation, and in some cases the proportion can be even lower than $1 \%$. For the discussion, see Consumer Financial Protection Bureau (2015), p. 27-31; Mayer Brown (2013).

35 The attorneys' compensation on average ranges from 15 to 80 million dollars. And in some cases it is even higher. For the discussion, see Fitzpatrick (2010b), p. 831; Eisenberg and Miller (2010), p. 262; Davis and Lande (2008), pp. 902-903.

36 Brief of the American Antitrust Institute in Support of Respondents at 5, Bell Atl. Corp. v. Twombly, 550 U.S. 544 (2007) (No. 05-1126).

37 See, for example, Cavanagh (2010), p. 644.

38 See, for example, Fitzpatrick, supra note 33, p. 2047; Posner (2001), p. 266.
} 
all the damages caused by antitrust violations. But if an infringement has taken place, class actions lawsuits become in essence the only option for most victims to receive compensation. ${ }^{39}$ To sum up, compensation is an integral component of class actions, but it only serves a subsidiary function to deterrence.

\subsection{The Principle of Full Compensation in the European Union}

The policy preferences in EU competition law do not shape the private remedies in the form of deterrence. The primary objective is that of compensating victims of antitrust infringements, while deterrence can be seen as a mere side effect. For this purpose, the EU established the principle of full compensation for private enforcement, summarized in Table 1.

The beginning of the development of the principle of full compensation can be found in the CJEU's decision in the Crehan case. ${ }^{40}$ The CJEU expressly established that the full effectiveness of Art. 101 TFEU would be put at risk were it not open to any individual to claim damages for losses caused. ${ }^{41}$ Later, in the Manfredi judgement, the CJEU provided further elaboration that each injured party must be able to seek compensation not only for actual loss, but also for loss of profit plus interest. $^{42}$ In accordance with the CJEU judgments, the subsequent 2008 White Paper established the principle of full compensation that allows claims for damages for the real value of the loss suffered, taken together: (i) the actual loss, (ii) loss of profit, and (iii) the right to interest. ${ }^{43}$

The Directive reaffirms the EU acquis communautaire by providing that anyone has a right to claim full compensation for the harm caused by antitrust infringements. ${ }^{44}$ It also seeks to avoid overcompensation by rejecting any form of damage multipliers, such as the US treble damages. ${ }^{45}$ The principle of full compensation is reinforced by two additional provisions:

- Both direct and indirect purchasers are entitled to claim full compensation; ${ }^{46}$

- The injured party may claim compensation from any of the jointly and severally liable infringers until the claimant is fully compensated. ${ }^{47}$

Compared to the Directive, the Recommendation aims at facilitating access to compensatory justice for individual claimants, while there is no particular emphasis

\footnotetext{
39 Lande (2016), p. 81.

40 Courage, supra note 22.

41 Ibid, para. 26.

42 Joined Cases C-295/04 to C-298/04 Vincenzo Manfredi and Others v. Lloyd Adriatico Assicurazioni SpA and Others [2006] ECR I-6619, paras. 95-97.

43 White Paper, supra note 25, Sec. 2.5.

44 Directive, supra note 4, Art. 1.

45 Ibid, Art. 3(3).

46 Ibid, Arts. 12 and 14.

47 Ibid, Art. 11(1).
} 
Table 1 A study of the principle of full compensation of damages

Principle of full compensation of damages

Main provisions

Crehan judgement

The right of any individual to claim damages

\section{Manfredi judgement}

Any individual must be able to seek compensation not only for actual loss (damnum emergens) but also for loss of profit (lucrum cessans) plus interest

White Paper (2008)

Full compensation covers the real value of the loss suffered: (i) the actual loss, (ii) loss of profit, and (iii) the right to interest

Directive on damages actions (2014)

Any natural or legal person should be able to claim and obtain full compensation for the harm caused by an infringement. Full compensation shall therefore cover the right to compensation for actual loss and for loss of profit, plus the payment of interest

Recommendation on collective redress (2013)

Collective actions facilitate access to justice and enable compensation to individual claimants in mass harm situations
The relationship with full compensation principle

The initial confirmation of full compensation by the CJEU

The CJEU extension of the compensation objective including the expected loss (loss of profit and interest)

Confirmation of the full compensation principle in the non-binding document of the European Commission

Confirmation of the full compensation principle in the legally binding document of the European Union

The primary objective is to facilitate access to justice and to enable compensation in mass harm situations. There is no particular emphasis on full compensation

on full compensation. ${ }^{48} \mathrm{~A}$ logical implication of this would seem to be that there is no intention to regulate the competition law on a sectorial basis, since the Recommendation takes a horizontal approach (across a range of sectors). Thus, there is no reason why the principle of full compensation and avoidance of overcompensation should not guide the proceedings of antitrust collective actions.

Any damages actions reform that seeks to ensure the right to full compensation, also commits to implement a scheme that allows for victims to exercise that right at all distribution levels. A primarily compensation-oriented system frames a procedural framework that implicitly acknowledges the progression of successive determinants. ${ }^{49}$ First, by promising full compensation, the EU reform accepts that each financial victim of the antitrust infringement can claim compensation for the harm suffered. Therefore, it means that standing should be granted to direct purchasers and to indirect purchasers all the way down the distribution chain. In

\footnotetext{
${ }^{48}$ However, para. 30 of the Recommendation mentions the right to full compensation, but in the context of contingency fees. It remains unclear how this provision would interact with the principle of full compensation enshrined in the Directive on damages actions.

49 The progression regarding the compensation objective in the 2008 White Paper was observed by the American scholarship. See Crane, supra note 31, pp. 682-683. In this paper, the discussion has been extended on the basis of the EU damages actions reform.
} 
addition, the indirect purchasers can rely on a rebuttable evidential presumption that cartel overcharges are at least partially passed on to them. Therefore, exercising the right of indirect purchasers would require chasing the "harm downstream to the ultimately injured parties" (usually totalling thousands or even millions indirect purchasers) who usually suffer dispersed and low-value damages. ${ }^{50}$ To complicate matters further, the right to seek full compensation encompasses the real value of the loss suffered, including the actual loss, lost profits and interest. All things considered, the EU has introduced a mechanism that demands a very effective compensation scheme, since every victim is entitled to full compensation. This objective sounds laudable, but in reality the enforcement of full compensation requires the implementation of at least the following elements illustrated in Table 2.

First, the effectiveness of compensation depends on whether victims actively engage in private litigation. However, the further down the distribution chain victims are, the more remote they are from the violation and the less incentives they have to litigate. Therefore, the main alternative for collecting scattered individual losses is the availability of effective collective redress schemes. But identifying, collecting and compensating antitrust victims can be very burdensome, especially if they are located far down the supply chain. It is also true that collective actions would never be heard if there was no sufficient ground for group representatives to take complex and expensive antitrust cases. Indeed, the potential award should outweigh the risks involved. In addition, regardless of how distant victims are from the infringement, the discovery rules should enable receiving incriminating evidence. Otherwise, establishing, proving and quantifying damages may be an insurmountable task. Considering these factors, it will be further examined whether or not the proposed measures in the damages actions reform (in the Directive and in the Recommendation) are likely to achieve the objective of full compensation.

\section{The Fulfilment of Optimal Compensation Under the EU Private Antitrust Reform}

\subsection{An Overview of the Directive}

When designing a system of private antitrust enforcement, policymakers had to strike a delicate balance between public and private enforcement. Yet, in spite of the declared goal to facilitate damages claims, the new Directive first and foremost seeks to preserve the effectiveness of public enforcement, and leniency programs in particular. Despite the strong focus on public enforcement, some provisions are of particular relevance to consumer actions, such as granting standing to indirect purchasers. The main features of the Directive are therefore analysed through the lens of optimal compensation.

50 Ibid. 
Table 2 The determinants of an effective enforcement of the principle of full compensation

An effective enforcement of full compensation

Full involvement of victims

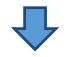

The availability of effective collective redress schemes

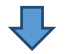

The potential ground for representatives to represent victims

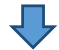

Discovery rules enable the disclosure of incriminating evidence

\subsubsection{Access to Evidence}

With the Pfleiderer judgement, the CJEU introduced a large dose of concern for potential leniency applicants. Most importantly, the Court refused to ensure the protection of leniency submissions. Considering the absence of EU rules on disclosure, the national courts were entitled, in each case, to carry out the balancing test for granting access to leniency documents. ${ }^{51}$ Hence, it became difficult to predict how national courts would treat each request for access to leniency material.

With a view to remedy an unpredictable Pfleiderer's case-by-case test, EU legislators introduced two limitations in the Directive: (1) leniency statements and settlement submissions have absolute protection from disclosure (the so-called black-listed documents); and (2) information prepared specifically for the regulatory investigation until the competition authority has closed its proceedings, as well as withdrawn settlement submissions, are granted temporary protection from disclosure (the so-called grey-listed documents). ${ }^{52}$ Other documents falling outside the scope of these two categories should be subject to disclosure at any time (the socalled white-listed documents). One of the most important provisions is that the courts are enabled to order disclosure at their discretion. An important facilitation for plaintiffs is that defendants and third parties can be forced to grant access to documents to the other side. However, national courts are required to limit the disclosure of evidence in consideration with the following points: ${ }^{53}$ (1) the plaintiff has pleaded facts and evidence justifying the request to disclose evidence; (2) the plaintiff's request is accompanied by a "reasoned justification" to support the plausibility of the suit; and (3) the requested evidence should be defined as precisely and narrowly as possible, and national courts must confirm the proportionality of the disclosure. To sum up, the court shall perform a balancing test on a case-by-case

\footnotetext{
51 Pfleiderer, supra note 28, para. 32.

52 Directive, supra note 4, Art. 6.

53 Ibid, Art. 5.
} 
basis, and hence decide whether the requested documents fall under the white list category and whether the request is proportional.

At first sight, relatively broad disclosure rules may increase the probability of incriminating evidence about the real harm caused to the victim being revealed, even if leniency statements and settlement submissions are not part of disclosure. For example, by allowing the disclosure of more direct evidence (such as prices, sales volumes, profit margins or costs), the Directive allows a better estimation of how the alleged infringement affects a particular market situation, and how the harm can be quantified. ${ }^{54}$ Hence, it may solve the information asymmetry between plaintiffs (such as end consumers) and defendants (such as large corporations), who hold a monopoly regarding the evidence of violation.

\subsubsection{Joint and Several Liability}

Article 11 of Directive introduces the concept that infringers are jointly and severally liable for the entire harm caused by the joint infringement. Under this provision, each victim has the right to claim full compensation from any of the co-infringers until the harm is fully recovered. The court is responsible for determining the magnitude of liability, based on the extent of the harm caused by co-infringers. As regards immunity recipients, a conditional limitation of joint and several liability applies to immunity recipients, once again to avoid the negative and unpredictable effects on the leniency program. ${ }^{55}$ In principle, they will be jointly and severally liable to their own purchasers (direct and indirect) only. However, the leniency recipients may be held liable if injured purchasers cannot obtain full compensation from the co-infringers. ${ }^{56}$ It can be acknowledged that the Directive seeks to ensure the entire co-cartelists' responsibility for the infringement, yet the civil liability for damages should be the least severe for the immunity recipient.

\subsubsection{Indirect Purchasers}

The new rules on standing are the most important improvement for consumer actions. In accordance with the principle of full compensation, Art. 15 of the Directive extends standing to both direct and indirect purchasers. Indirect purchasers are natural or legal persons who acquired products or services (which are subject to competition law violations) not directly from a wrongdoer, but from a direct purchaser or a successive purchaser. ${ }^{57}$ This is a class category that usually includes downstream consumers and SMEs, who are indirectly affected by

\footnotetext{
54 Practical Guide on Quantifying harm in actions for damages based on breaches of Arts. 101 or 102 of the Treaty on the Functioning of the European Union, accompanying the Communication from the Commission on quantifying harm in actions for damages based on breaches of Arts. 101 or 102 of the Treaty on the Functioning of the European Union SWD (2013) 205, para. 30. The Guide observed that the availability of direct evidence may be useful information for assessing the quantum of damages.

55 Directive, supra note 4, Art. 11(4).

56 Ibid.

57 Ibid, Art. 2.
} 
competition infringement, particularly when antitrust overcharges are passed down to them in the supply chain. However, it is true that consumers and SMEs can both acquire cartelized products as direct and indirect purchasers. Arguably, the expansion of standing is in conformity with the Courage and Manfredi decisions that grant standing to every (direct and indirect) victim of anti-competitive behaviour. This approach differs from that in the United States at the federal level. The US Supreme Court rejected the passing-on defence in the landmark Hanover Shoe decision. ${ }^{58}$ From an economic rationale, it is considered that direct purchasers are best suited, and hence most likely, to bring antitrust claims. ${ }^{59}$ Almost a decade after Hanover Shoe, the Supreme Court ultimately denied standing to indirect purchasers to bring antitrust claims. ${ }^{60}$ Conversely, indirect purchasers may recover damages in some state law actions. ${ }^{61}$

With regard to the EU, the standing to indirect purchasers is reinforced through the inclusion of a rebuttable presumption. Accordingly, the indirect purchaser is considered to have proven that (at least some of) the overcharge levied on a direct purchaser has been passed on to him or her when the following points are shown: ${ }^{62}$

- The defendant has breached competition rules;

- The violation has resulted in an overcharge for the direct purchaser;

- The indirect purchaser purchased the goods or services concerned.

If all factors have been demonstrated to a credible extent, the court should approve the presumption of passing-on. In contrast, most EU countries have to date required proof of the overcharges in claims of indirect purchasers. ${ }^{63}$ Therefore, the EU facilitation is very helpful for indirect purchasers, who are typically far removed from the defendant, and for whom the substantiation of the overcharge is particularly burdensome.

In order to avoid overcompensation for purchasers, the Directive accepts the availability of the passing-on defence. ${ }^{64}$ The defendant can invoke this type of defence against a damages claim if the claimant passed the overcharge on to the next level of the distribution chain, either fully or partially. The defendants are imposed the burden of proving the passing-on "credibly to the satisfaction of the court." 65 To facilitate the defendant's burden of proof, the defendants are able to request reasonable disclosure from the claimant or from third parties. It is clear that the defendants usually lack information, and access to information, on the relationship between a direct purchaser and a subsequent purchaser, including information on the price of the resale.

\footnotetext{
58 Hanover Shoe, Inc. v. United Shoe Mach. Corp., 392 U.S. 481 (1968).

59 Oxera (2014).

60 Illinois Brick Co. v. Illinois, 431 U.S. 720, 729-730 (1977).

61 See, for example, California v. ARC Am. Corp., 490 U.S. 93, 105-06 (1989).

62 Directive, supra note 4, Art. 14(2).

63 European Commission (2015), p. 3.

64 Directive, supra note 4, Art. 13.

65 Ibid, Art. 14(2).
} 


\subsubsection{The Existence of Harm}

Article 17 of the Directive establishes a rebuttable presumption that cartels cause harm. The alleged violator bears the burden of rebutting that presumption. In simple terms, a final decision by the Commission, national competition authorities or by a review court should be established as irrefutable evidence of harm that can be used for the purposes of a follow-on damages claim. However, even though the requirement to prove harm is removed, a claimant is still required to prove causation, loss and the quantum of damages. In addition, the Directive empowers the courts to estimate the quantum of harm based on reasonably available evidence, provided it is "practically impossible or excessively difficult" for the claimant to estimate the amount of harm suffered based on the available material. ${ }^{66}$ For this purpose, the Commission issued the Practical Guide on how to quantify damages. ${ }^{67}$ Yet, such estimates are based on complex, unpredictable econometric models. In addition, the final decisions taken by the competition authorities or courts of one Member State will constitute at least prima facie evidence before civil courts in other EU countries. ${ }^{68}$ However, this type of finding has already been recognized in many EU jurisdictions, even before the adoption of the Directive.

\subsection{The Commission's Model of the Recommendation}

The main principles of the collective redress mechanisms that the Commission expects the Member States to adopt include the following:

- As a general rule, collective redress claims should be pursued on an opt-in basis, requesting the express consent of victims. Any exception to this rule should be "duly justified by reasons of sound administration of justice." 69

- The systems of collective redress should cover both injunctive and compensatory collective redress actions.

- A coherent collective redress scheme should be ensured by procedural safeguards in order to avoid the development of abusive litigation, such as in the US class action system. ${ }^{70}$ According to the Recommendation, these safeguards must cover, inter alia:

(i) Contingency fees should not be permitted. But, if a Member State allows for such a reimbursement model, it should be subject to appropriate national regulation; ${ }^{71}$

(ii) Punitive damages must be prohibited in collective redress claims;

(iii) The "loser pays" principle is a central safeguard against abusive litigation;

\footnotetext{
66 Ibid, Art. 17(1).

67 Practical Guide, supra note 54.

68 Directive, supra note 4, Art. 9.

69 Recommendation, supra note 5, para. 21.

70 Recommendation, supra note 5, para. 1.

71 Recommendation, supra note 5, para. 30.
} 
(iv) There must be limitations on third-party funding. The funders should be free from conflicts of interest, and they should have sufficient funds to support the legal action.

In terms of standing, the European Commission recommends two types of collective redress mechanisms:

- Group actions brought jointly by natural and legal persons who claim to have suffered harm;

- Representative actions.

Group actions are very poorly defined in the Recommendation, only stating that "the issue of standing [in group actions] is more straightforward than in the context of representative actions." 72 Indeed, the key policy emphasis is on representative actions brought by representative entities, which should be limited to ad hoc certified entities or representative entities designated in advance. The EU approach sets stringent requirements for ad hoc or general certification, such as a non-profit character, a direct relationship between the violation and the activities of the representative entity, as well as sufficient capacity in terms of financial resources, human resources and legal expertise. ${ }^{73}$

It is expected that the proposed principles of the Recommendation will facilitate access to justice, as well as facilitating compensation in mass harm situations. Given that the Recommendation is the most concrete step in the field of collective redress, the following discussion produces a study on the extent to which the proposed measures in the Recommendation (in combination with the Directive) fulfil the objective of full compensation that is embedded in EU private antitrust reform.

\subsection{The Assessment of the EU Private Antitrust Reform: A Study of Full Compensation}

It is a very challenging task to combine the effectiveness of public enforcement and private enforcement on the one hand, and of giving standing to direct and indirect purchasers on the other, especially if there is an intention to ensure the victim's effective right to full compensation. While trying to achieve much in one fell swoop, the reform is in fact most likely to fail in providing full compensation, both for direct and indirect purchasers.

First, the EU has expressed the concern that private actions might actually undermine the effectiveness of the leniency programme, a crucial tool in exposing long-term cartel violations and in bringing them to an end. ${ }^{74}$ Thus, there is a need to secure public enforcement by ordering protection from disclosure of leniency statements and settlement submissions. Yet, in order to qualify for leniency, the applicant has to provide the incriminating evidence of the alleged cartel, as well as a corporate statement that incriminates the receiver of the potential leniency. ${ }^{75}$

\footnotetext{
72 Ibid, rec. 17.

73 Ibid, para. 4.

74 Directive, supra note 4, rec. 38.

75 Commission Notice on immunity from fines and reduction of fines in cartel cases [2006] OJ C298/17, paras. 9-11.
} 
Therefore, the inherently incriminating evidence will always be kept in the Commission's leniency file, and will not be available to victims. In fact, the inaccessibility of incriminating evidence reduces the incentives to bring follow-on damages claims, as other types of evidence (prices, profit margins or costs) are unlikely to characterise cartels as well as leniency material. Even though the Directive approves two rebuttable presumptions - one being that cartels cause harm and the other being that overcharges are passed on to indirect purchasers - it does not alleviate the burden to prove the harm suffered. Indeed, there are considerable difficulties in showing that, for example, indirect purchasers have indeed purchased goods that were the object of the competition law infringement.

The possibilities to bring stand-alone actions raise even more doubts. These actions are discouraging because they require a high standard of proof that the harm has actually occurred, without being able to rely on the findings of public enforcers. But, when compared with follow-on claims, the conviction rate is assumed to be lower, and thus the likelihood of receiving damages is also lower. ${ }^{76}$ Moreover, calculations of overcharges and disclosure come at high costs, especially when there is no prior public enforcement. The logical solution would be to reinforce private actions by assertive measures with regard to standing and funding so as to incentivize claimants to invest time and money in stand-alone claims. However, currently the only facilitation is that the Directive allows for the court to decide whether or not relevant evidence should be disclosed. ${ }^{77}$ Indeed, the Directive enhances legal certainty for stand-alone actions that potential evidence may be disclosed through court orders. But it is highly unlikely that such facilitation will increase the incentives to litigate cumbersome stand-alone claims. The incentive is reduced even further given that rational claimants will assume the risks of receiving too little or no relevant evidence; after all, national judges are unpredictable.

By preventing stand-alone actions, the Directive significantly diminishes the objective of full compensation, which is to provide compensation to any injured party. To explain this, it should be stressed that competition authorities usually take cases that have high rates of conviction. For example, around $60 \%$ of cartel infringements are uncovered due to the leniency programme. ${ }^{78}$ Under this model, investigatory tools are generally not used to reveal cartels; whistle-blowers come forward on a voluntary basis. The subsequent issue is that the detection rate of cartels is only up to $33 \%$ in the EU. ${ }^{79}$ Consequently, a large majority of cases are bound to go undetected, and therefore victims will remain uncompensated, as private enforcers are unlikely to bring stand-alone actions.

Second, the reform has extended the standing to direct and indirect purchasers (including consumers and SMEs). Despite of the compensation of any injured party sounding laudable in theory, the reform is controversial because neither direct

\footnotetext{
76 Renda, supra note 3, p. 153.

77 Directive, supra note 4, Art. 5.

78 See, for example, Carmeliet (2011-2012), p. 463.

79 See Smuda (2012), p. 19; Combe and Monnier-Schlumberger (2009), pp. 41-43. The latter authors estimated that the detection rate was around 15\% during 1975-2009. Some commentators observe that the $15 \%$ detection rate of a cartel is an upper bound, see Mariniello (2013), p. 2.
} 
purchasers nor indirect purchasers (and especially not end consumers) can effectively exercise the right to claim full compensation.

The favourable treatment of end purchasers raises many obstacles to the achievement of the compensation goal in direct purchaser cases. The acceptance of the passing-on defence might prevent direct purchasers from bringing damages claims. If a pass-on presumption has been confirmed, the direct purchaser would receive the reduced damages based on the amount passed on to subsequent purchasers. ${ }^{80}$ It is even possible that a direct purchaser may pass on all or part of an overcharge to downstream consumers, but in reality "a direct purchaser has absorbed an overcharge in part or full"; this situation is contrary to the economic rationale. ${ }^{81}$ There is also a concern that the successful application of the passing-on defence is not in line with the application of the principle of full compensation, which awards compensation not only for the actual loss but also for loss of profit plus interest. A scenario is possible in which direct purchasers are not entitled for actual loss on the basis of the harm being passed on to indirect purchasers, but they would succeed in claiming damages for loss of profits, for example when the increased costs reduce revenues compared to what they would have obtained in a non-infringement scenario (in other words, counterfactual loss of profits). ${ }^{82}$

When the availability of indirect purchaser claims is combined with the passingon defence, it makes it very difficult to define how much of the cartel overcharge is actually passed down through each distribution level (both for direct and indirect customers). ${ }^{83}$ Further down the distribution chain, more complex factual and economic analysis is typically required in order to quantify the overcharge. It can therefore be acknowledged that the number of victims increases proportionally down the distribution chain. ${ }^{84}$ End consumers usually stand at the very end of the distribution chain, and the harm they suffer is of scattered and low impact. Unsurprisingly, these victims have the weakest interest in bringing damages claims, because they possess little information about the nature and extent of the harm and, most importantly, the cost-benefit of the claim is negative. Therefore, there is a high possibility that antitrust infringers will avoid responsibility for the harm caused when the overcharge was passed down the distribution chain.

Most likely, the only way to reach each victim (including end purchasers) and therefore to stand firm against the wrongdoers is the possibility of aggregating suits and pursuing them together through collective actions. Despite being the vital amendment in any form of antitrust damages reform, the issue was only dealt with in the non-binding Recommendation. Yet, the problem is not that the effectiveness is considerably limited by the non-binding nature. The real issue is that the current EU policy inherently limits the facilitation of access to justice to any injured victim as long as the collective redress scheme is framed under the proposed principles of the Recommendation. There are at least four reasons why the objective of fully

\footnotetext{
${ }^{80}$ Peyer (2015), p. 25.

81 Oxera, supra note 59.

82 Büyüksagis (2015), p. 25.

${ }^{83}$ Ibid, 24 (citing Maier-Rigaud (2014), p. 341).

${ }^{84}$ Drexl (2015), p. 2.
} 
compensating victims with small stakes is destined to fail if the proposed principles of the Recommendation will ever take a legally binding form.

\subsubsection{The Ineffectiveness of an Opt-In Principle}

First, the national experiments in France ${ }^{85}$ and the $\mathrm{UK}^{86}$ reveal the inefficacy of optin collective actions in attracting a sufficient number of victims to make an action economically feasible. ${ }^{87}$ Despite an extensive media campaign in both countries, only a few hundred victims joined the action, while the violations had potentially caused harm to millions of consumers. ${ }^{88}$ These failures can be easily explained. The potential awards were so low (the individual harm was on average $€ 60$ in France and $£ 20$ in the UK) that victims simply did not care about possibilities to join the action. Furthermore, many of them appeared to be unaware that they were harmed by the alleged cartel.

Second, the US experience shows the lack of responsiveness of class members when affirmative steps are required, even when they are entitled to an award. As mentioned before, only up to $20 \%$ of class members in the US file claims to receive payments when settlement distribution requires class members to file claim forms. At its core, an opt-in measure is much more dissuasive than claim forms, because there is no guarantee of any recovery at all (the probability of success is much less than 100\%). Furthermore, victims can be required to pay membership fees in order to opt into the action.

\subsubsection{The Interrelated Problems of Standing and Funding}

One of the most attractive designations to bring representative actions is a non-profit consumer organisation or other public body (for example, an ombudsman or a trade union), as these entities are incentivised by their organisational mission to represent consumers in line with their best interests (at least in theory). ${ }^{89}$ However, in reality there is a lack of rational actors who would have the capacity to bring risky, complex and costly collective competition actions under conditions of eligibility.

\footnotetext{
85 In France, after the Competition Council decision (Counseil de la concurrence, Decision No. 05-D-65 of 30 November 2005), the consumer organisation UFC-Que Choisir brought an opt-in collective antitrust claim on the basis of price-fixing made by three mobile operators.

${ }^{86}$ In the UK, the consumer association Which? sued JJB Sports for fixing prices of replica football kits. An opt-in collective claim was based on the following decisions: OFT decision of 1 August 2003 No. CA98/06/2003; Allsports Limited, JJB Sports plc v. Office of Fair Trading [2004] CAT 17; Umbro Holdings Ltd, Manchester United plc, Allsports Limited, JJB Sports plc v. Office of Fair Trading [2005] CAT 22; JJB Sports plc v Office of Fair Trading [2006] Court of Appeal, EWCA Civ 1318.

87 "Which?" stated that low number of consumers joined the action to make it feasible, and only an optout scheme would ensure the financial feasibility. See Which? (2011).

${ }^{88}$ Out of 20 million victims, the UFC-Que Choisir managed to collect claims from only 12,350 consumers. Out of 2 million victims, Which? managed to collect claims from only 130 consumers.

${ }^{89}$ Buccirossi et al. (2012), p. 68. However, public standing cannot fully remedy the principal-agent problem. The decisions of the public entity may be influenced by political groups. For example, if a powerful company infringes on competition law (for example, by price-fixing), it may be able to influence the decisions of the association through political groups.
} 
For example, consumer organisations in many EU States have limited or no public funding, and if they are financed, then it is only on an annual basis, preventing them from acting for instance in the form of a court action. ${ }^{90}$ An even more worrisome factor is that consumer organisations are struggling for survival in some countries, and consequently have a small number of paid staff. ${ }^{91}$ In fact, the idea that these entities would be able to fulfil the EU Recommendation's requirements for designated representative entities, i.e. having sufficient financial resources, human resources, and legal expertise, sounds rather anecdotal. ${ }^{92}$

The picture is somewhat different, for instance, in the $\mathrm{UK}^{93}$ and France, ${ }^{94}$ where specified wealthy consumer organisations are entitled to bring a claim on behalf of consumers in relation to damages for breach of antitrust law. However, the abovementioned opt-in actions raised a general issue of funding that was not resolved simply through organisational standing. In case of representation by a group member, the issue of funding is even more evident: group members are unlikely to have more capacity in terms of funding and resources. This suggests that another important determinant for compensating victims is the incentive for potential intermediaries to bring claims on behalf of these victims. If a solution was found, the objective of compensation would be better achieved; the logic is simply that the more actions are brought, the more victims are compensated.

\subsubsection{No Involvement of Private Litigators}

The US experience suggests that the most important consideration from the standpoint of a plaintiff, and more specifically a class counsel, is whether the expected awards outweigh the expected risks of bringing complex antitrust actions. In the US, this objective is achieved because the private antitrust mechanism combines five deterrence-based tools: an opt-out measure, contingency fees, treble damages, one-way fee shifting (the absence of the "loser pays" rule), as well as wide-ranging discovery. The biggest difference from the EU is that the US deterrence-oriented system urges active involvement of private litigators through the scheme of the private attorney general. In the EU context, however, a more active role of private litigators is limited by the conservative approach to respecting the different legal systems and traditions of the Member States, and also to preventing any possibilities of overcompensation. Therefore, the EU rejects the contingency fee agreements, while third-party funders are subject to the strict eligibility test. ${ }^{95}$ Also, opt-out schemes and multiple damages are seen as contrary

\footnotetext{
90 Howells and Micklitz (2009), p. 20.

91 Kutin (2011), p. 106.

92 Recommendation, supra note 5, para. 4.

93 Section 47B of the Competition Act 1998 allows representative actions to be brought in the Competition Appeal Tribunal by a "specified body" on behalf of consumers for damages for violation of UK or EU competition law.

94 Under Art. 421-1 of the Consumer Code, an authorized consumer association may exercise the "rights given to a civil party relating to facts which cause direct or indirect harm to the collective interests of consumers, prejudicing the collective interest of consumers."

95 Recommendation, supra note 5, paras. 14, 30.
} 
to the legal traditions of the EU and its Member States. In such circumstances, it seems highly unlikely that rational actors would have sufficient incentives to serve as class representatives or bring complex competition law collective action without the expectation of significant awards.

\subsubsection{Collective Actions Are so Costly that They Consume a Large Portion of the Award}

The last issue is that full compensation is rather unrealistic for claimants who participate in the action, due to the organisation of the group requiring large organisational costs, including both administrative costs and case-management costs. ${ }^{96}$ In order to inform the affected parties of the litigation, and to thus attract them to join the action, opt-in collective actions require expensive awarenessraising campaigns through mass media and other information channels. These problems are well illustrated by the Mobile Cartel opt-in collective action in France. The litigation costs were around $€ 0.5$ million, while the total value of the claim was $€ 0.8$ million (12,530 consumers joined the action with an average claim of $€ 60) .{ }^{97}$ Much less than $1 \%$ of consumers joined the action, but the litigation required the hiring of 21 employees, and 2,000 hours were consumed to prepare the action. ${ }^{98}$ In cases where opt-out schemes are used in practice, all victims become parties in the action and thus the group is already organised. Therefore, the organisational costs should be lower than in opt-in actions. However, as the US experience has shown, identifying the potential class members, processing the litigation and distributing the damages also causes significant costs. ${ }^{99}$ To sum up, the total costs for bringing collective damages actions remain significant regardless of the type of representative action preferred by policymakers (an opt-in and/or an opt-out), because of the complexity of legal and economic assessments and a high burden of proof.

\subsection{Synopsis}

The antitrust damages reform's objective of fully compensating victims of all types fails to a large extent for at least three reasons.

\subsubsection{Public Enforcement Remains the Predominant Tool in Antitrust Enforcement}

The principal aim of the Directive on damages actions is to preserve strong public enforcement. The main emphasis is on protecting leniency documents in follow-on private actions, where victims can free-ride on the efforts of competition authorities. Yet, the protection of leniency documents diminishes the motivation to bring follow-on actions, as inherently incriminating evidence is protected. Other documents are unlikely to describe the violation as well as leniency materials.

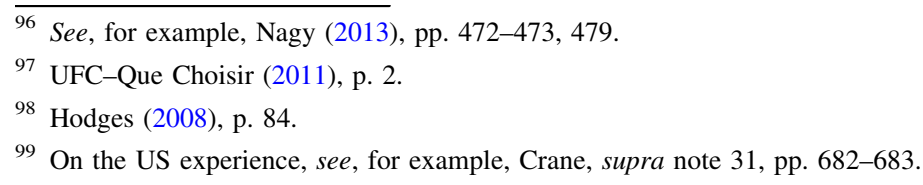




\subsubsection{There Are No Sufficient Incentives to Bring Stand-Alone Actions}

The only facilitation of stand-alone actions is the court ordering disclosure, which is also dependant on the judge's willingness to disclose the relevant documents. However, the provisions on effective funding tools and favourable rules for standing are disregarded in the Directive. In absence of these tools, the chances that standalone claims will be brought to courts are rather incidental. In fact, by preventing stand-alone actions, the Directive simultaneously prevents private enforcement from resolving the public enforcement's shortcoming of low detection rates.

\subsubsection{Victims and Their Representatives Are Discouraged from Bringing Collective Actions}

The reform fails to maintain a balance between the claims of direct and indirect purchasers. The special treatment of the indirect purchaser makes litigation cumbersome for direct purchasers, as the defendants can invoke the passing-on defence. A rebuttable pass-on presumption may create a situation where an overcharge levied on direct purchasers will have been passed to their own downstream consumers, but in essence a direct purchaser has absorbed an overcharge. Ironically, despite the new right for indirect purchasers to seek compensation before national courts, it remains worthless if Member States would follow the proposed principles of the Recommendation. Essentially, the proposed opt-in measure limits the access to justice to any injured party. Furthermore, there is a lack of rational actors who would serve as class representatives by taking on the risks of complex antitrust actions. This is especially true given that there are no tools for enabling sufficient compensation, which could outweigh the risks.

Despite the objective of compensating indirect purchasers being predetermined to fail, there is high potential for direct purchasers (particularly big businesses) bringing more damages actions. In 2015, a year before the Directive on damages actions was implemented in the Member States, there were 64 pending cartel damages claims in ten EU Member States. ${ }^{100}$ However, a large majority of actions were brought by large corporations that purchased directly from the violators. There is also an increased possibility for arbitration in antitrust damages claims. The Directive enables parties to secure damages through consensual dispute resolution mechanisms, such as out-of-court settlements and arbitration. ${ }^{101}$ However, it should be stressed that arbitration will be subject to conditions in damages claims. ${ }^{102}$ Also, arbitration in collective actions seems highly complex, and potentially impossible in most cases, as not all group members will be necessary in contractual relations, or they may lack pre-existing arbitration agreements. ${ }^{103}$

Given that damages claims were unavailable in many EU States, and that the Directive has only recently been incorporated into national laws (or soon will be),

\footnotetext{
${ }^{100}$ BarentKrans, supra note 21.

101 Directive, supra note 4, rec. 48.

102 Driessen-Reilly (2015), pp. 575-576.

103 See Živković (2017).
} 
cartel damages claims (and potentially arbitration cases) should become a trend across the Member States. The most alarming factor is that indirect purchasers (SMEs and consumers) or direct purchasers with small claims will continue to struggle to receive damages, since forceful collective redress schemes were not included in the Directive. In turn, it will create incentives for "forum shopping" by choosing the jurisdictions that allow for opt-out collective actions (such as Portugal, the Netherlands and the UK). However, litigating in other fora requires significant financial resources, which vulnerable victims lack. As a result, a large majority of victims will remain uncompensated.

\section{The Impact of Deterrence-Based Tools on the EU Compensatory Collective Actions}

As already discussed, US class actions are primarily designed to serve the objective of deterrence. This does not eliminate the importance of compensation, but it remains a mere secondary tool after deterrence. In marked contrast with the US, and regardless of the complexity of detecting victims and compensating them, the EU system primarily focuses on ensuring full compensation for the damage actually incurred. In an effort to appropriately assess the rationale of full compensation, the following discussion will examine the importance of deterrence-based remedies in the EU system. ${ }^{104}$

\subsection{The Need for Damage Multipliers}

In the US, automatic treble damages are the key deterrent to potential infringers. ${ }^{105}$ In addition to deterrence, treble damages are also expected to provide "ample" compensation to antitrust victims. ${ }^{106}$ However, trebling has no fairness criteria of fully compensating victims; rather, it seeks to provide "rough justice" to sufferers. ${ }^{107}$ Furthermore, the US experience offers the lesson that treble damages actions are typically settled, and hence the award generates amounts closer to actual damages rather than treble damages. ${ }^{108}$ When the high administrative costs are deducted from this award, basic economic logic essentially demonstrates why antitrust class actions provide very low proportional compensation to an insignificant number of victims. But, as mentioned before, the compensation failure can be justified if the deterrent function is successful.

\footnotetext{
104 This point was discussed by Professor Crane several years ago. See Crane, supra note 31, pp. 700-702. The following discussion in this article has been expanded on the basis of the EU private antitrust reform.

105 Mitsubishi Motors Corp. v. Soler Chrysler-Plymouth, Inc., 473 U.S. 614, 635 (1985).

106 Blue Shield of Va. v. McCready, 457 U.S. 465, 472 (1982).

107 Cavanagh, supra note 37, p. 632 (citing Lande (1993), p. 118). Cavanagh provides a monopolisation example where the difficulties occurred in reconstructing the "but for" test in the case LePage's, Inc. v. $3 M$ Co., 324 F.3d 141, 164-66 (3d Cir. 2003) (en banc), cert. denied, 542 U.S. 953 (2004)).

108 Ibid, p. 644; Boies (2004), p. 333.
} 
The EU approach is much more precise than that in the US. It has the explicit aim of providing actual compensation and the expected loss (lost profits and interest). Nonetheless, the EU is in a deadlock situation: the EU scheme seeks to ensure full compensation to all victims, but this goal is bound to fail. After all, there is no way to bypass the compensation failure, as in the US. To make matters even more complex, opt-in claims are very costly, since the group needs to be organized (as shown in the Mobile Cartel litigation). Consider a scenario where victims are awarded full damages: in reality they would not receive them, because the case related costs would consume a large portion of the recovery. In case of settlement, the compensation failure is even more inevitable, because full damages would never be awarded. In order to solve the ineffectiveness in fully compensating victims, the EU scheme requires additional financial reinforcement to cover the costs related to the enforcement of the compensation goal (full damages + case related costs). One solution, if not the only one, would be to allow a damage multiplier in the EU context. It would ensure the award of full damages even after deducting the caserelated costs. We can therefore acknowledge that while the damage multiplier is considered to have the potential to lead to overcompensation, in reality it is not bound to do so. It really varies from case to case, and depends on the size of the multiplier to be applied. In summary, while trebling is primarily aimed at ensuring the deterrence standards in the United States, some sort of damage multipliers are required to ensure the essential requirements when enforcing the objective of compensation in the European Union.

\subsection{The Need for Broad Discovery Rules}

The objective of ensuring full compensation all the way down the supply chain is also not in accordance with the limited discovery rules. First, they prohibit the disclosure of leniency statements and settlement submissions. Second, they are also potentially limited due to the court ordering disclosure. Such a restrictive model is of particular relevance for vulnerable victims. The first category contains direct purchasers, where each has only suffered harm. The second category includes indirect purchasers, who are spread out among different distribution chains. The specific feature of indirect purchasers is that the further down the distribution chain they are, the less facts and evidence have to prove that the discovery requests are proportionate under Art. 5 of the Directive.

It seems rather unrealistic that rational representatives would bring stand-alone cases on behalf of vulnerable victims when the main and potentially only facilitator is the court ordering disclosure. In these cases, a wide disclosure is especially important for the certification stage. ${ }^{109}$ However, collective actions seem too risky without fully knowing whether or not the judge will disclose the relevant material indeed, proving proportionality is a complex task. Another worrying factor is that

\footnotetext{
109 In the United States, for instance, the court requires to "present evidence that varies from member to member" in order to prove the commonality of the claim. See Blades v. Monsanto Co., 400 F.3d 562, 566 (8th Cir. 2005).
} 
the infringer has a monopoly on possessing the violating material. ${ }^{110}$ Therefore, the wrongdoer can structure the disclosure in a way that prevents incriminating evidence from ever being disclosed. Moreover, claimants may not be able to specify the evidence they need to support their case. When compared to public enforcers, private enforcers have far fewer investigation tools. But even follow-on actions do not seem very attractive under the current model. The problem is that white-listed documents are unlikely to characterise cartels as well as black-listed documents. And, in turn, there is no guarantee that they will contain evidence allowing quantification of the harm and to identify the full extent of the violation. This uncertainty acts as one of the major factors dissuading representatives from bringing collective claims on behalf of vulnerable victims.

In the context of the US system, cases of both categories are more attractive for legal representatives. Contrary to the EU, the US system allows for liberal partyinitiated discovery. ${ }^{111}$ Therefore, the Federal Rules of Civil Procedure allow flexibility in requesting the disclosure of depositions via oral and written depositions (Rules 28-32), written interrogatories (Rule 33), electronically stored information (Rule 34), and requests for admission (Rule 36). The US system is also unique, because even leniency applicants must provide "satisfactory cooperation" to the plaintiffs in their damages claims in order to enjoy de-trebling. ${ }^{112}$ The combination of these factors allows for the representatives to structure claims better. In turn, it becomes much easier to pass the certification stage and to prove damages.

To sum up, the US system, which bars indirect purchaser claims (at least at the federal level), has less need for broader discovery rules, since direct purchasers have more insight into the defendant's illegal practices (e.g. the quantum of harm caused by that infringement) than do indirect purchasers. ${ }^{113}$ Paradoxically, the US system has wide-ranging discovery rules in place, while the EU discovery is much more limited.

\subsection{The Need for Opt-Out Schemes and Assertive Funding Tools}

Antitrust violations (such as price-fixing cartels) often generate a low-value harm that is widespread geographically, and in some cases spread far down the distribution chain as well. One reason for this is that antitrust infringements last for several years, ${ }^{114}$ meaning that the market structure may change significantly during the violation period. Another reason is that antitrust damages can be spread in

\footnotetext{
110 See, for example, White Paper, supra note 25, Sec. 2.2 ("Much of the key evidence necessary for proving a case for antitrust damages is often concealed and, being held by the defendant or by third parties, is usually not known in sufficient detail to the claimant").

111 Federal Rules of Civil Procedure, Rule 26. For a discussion, see also Duns et al. (2016), p. 403.

112 Antitrust Criminal Penalty Enhancement and Reform Act, Pub. L. No. 108-237, §§ 201-214, 118 Stat. 666-67 (2004) (codified at 15 U.S.C. § 1 note). "Satisfactory cooperation" shall contain "a full account to the claimant of all facts known to the applicant ... that are potentially relevant to the civil action."

113 Crane, supra note 49, p. 702.

114 The law and economics scientists calculate that the mean duration of a cartel is around eight years. See Hüschelrath et al. (2012), p. 3; Smuda (2012), pp. 19-21.
} 
different directions, as antitrust harm can be passed on down the supply chain. ${ }^{115}$ As a result, collecting victims under an opt-in model, which requires convincing them to join the collective action, is simply unfeasible. First, these victims are not interested in investing time and effort in joining the claim, because the expected award is financially small by its very nature. Second, the violation may be so distant that detecting victims and compensating them can become a very complex, if not impossible task. ${ }^{116}$ Third, victims may be unaware of the violation, which can date back several years or more. In addition, one concern for legal representatives is that the "loser pays" principle is predominant, which can expose claimants to substantial adverse costs if the claim is lost. When combined with insufficient funding tools, it becomes clear why opt-in collective actions have been extremely unpopular in the EU Member States that do allow such a claim aggregation model. In contrast, the availability of opt-out actions has proved to be the main factor incentivizing collective actions to be brought in three jurisdictions: Portugal, ${ }^{117}$ the Netherlands ${ }^{118}$ and the UK. ${ }^{119}$ The proceedings are still on-going.

It should also be stressed that these collective actions have been reinforced by third-party funding, with the unique exception of Portugal. ${ }^{120}$ It shows that the efficiency of collective actions is directly related to the availability of opt-out schemes and forceful funding tools. In the US, class actions are mainly funded with contingency agreements for legal fees. ${ }^{121}$ When these fees are combined with treble damages and an opt-out aggregation model, class counsel is ensured to obtain compensation that outweighs the costs involved in antitrust collective litigation (if the case is successful). Under such a scheme, private attorneys are incentivised to invest in all types of cases. Even the claims of indirect purchasers may be of particular interest, as an overcharge is likely to affect a large group of victims, who are spread out down the supply chain. After trebling of the damages, the financial value of the class may be substantial, meaning that lawyers' compensation is also likely to be significant due to the contingency fee agreement. In the EU context, most States prohibit this reimbursement model in collective actions. In the few countries where contingency fee agreements are allowed in collective litigation,

\footnotetext{
115 Han et al. (2008), p. 2.

116 An illustrative example can be found in the decision of the Supreme Court of Canada, where the harm was identified, but that harm could not be proved to indirect purchasers. See Sun-Rype Products Ltd v. Archer Daniels Midland Company, SCC 58 [2013] 3 S.C.R. 545.

117 See Lisbon Judicial Court, case no. 7074/15.8T8LSB.

118 Equilib v. British Airways et al., Decision of 7 January 2015, District Court of Amsterdam.

119 The UK introduced amendments in the 2015 Consumer Rights Act in order to provide space for optout collective actions in competition law. As a consequence, two follow-on actions were brought in the UK: Dorothy Gibson v. Pride Mobility Products Limited and Merricks v. MasterCard.

120 The claim was filed by the Portuguese Competition Observatory, a non-profit association of academics. However, it is more the exception than the rule. The academics are likely experimenting with the new type of antitrust litigation.

121 Fitzpatrick, supra note 35, p. 832.
} 
they have not been utilized in antitrust practice. ${ }^{122}$ This is notable, because only optin schemes are allowed. In conclusion, the experiences in the EU Member States clearly demonstrate that compensatory collective actions are dependent on the USstyle tools of deterrence.

\subsection{Synopsis}

The EU's compensation-based mechanism, with a specific emphasis on full compensation, demands deterrence-based measures more than the US deterrencebased mechanism. Arguably, the principle of full compensation, in which the indirect purchaser rule is enshrined, is inherently created in order to cross the traditional EU compensation model. Despite this, the EU is inclined to employ the conservative approach to achieve full compensation.

On this point, it needs to be clarified that EU private antitrust enforcement is not exceptional in seeking to ensure the victim's right to full compensation. The principle of full compensation has been also embedded in European tort law, ${ }^{123}$ European contract law ${ }^{124}$ and in some legislative measures of the EU. ${ }^{125}$ Furthermore, the European Convention on Human Rights (ECHR) enshrines the right to compensation to the standard of "just satisfaction". ${ }^{126}$ According to some commentators, this compensation rule employs the so-called "Hull" formula, which demands the fulfilment of high standards: compensation needs to be adequate, effective, prompt and provided in full. ${ }^{127}$ Despite of the possibility of seeking full compensation in different fields, EU private antitrust enforcement is exceptional for encompassing not only the full award (actual loss plus expected loss), but also the availability of the claims of indirect purchasers. Indeed, this type of litigation is exceptional in competition law, yet it demands extensive enforcement powers. Does this show that the EU is overambitious in the field of antitrust? The answer is both yes and no. It is obvious that providing full compensation to indirect purchasers may be very complicated, or impossible in some cases, especially when indirect purchasers are very far removed from the violation. To make matters easier, EU

\footnotetext{
122 For the discussion, see Juška (2016). It was observed that contingency fees in collective litigation are allowed in Germany, Sweden, Lithuania and Poland. In the latter two countries, the participation of attorneys is mandatory in collective actions, and contingency fees are permitted with the least restrictions. But, there have been no antitrust collective actions on the basis of contingency agreements.

123 Principles of European Tort Law, Art. 9:101.

124 Principles of European Contract Law, Art. 9:502.

125 See, for example, Regulation (EC) No 261/2004 of the European Parliament and of the Council of 11 February 2004 establishing common rules on compensation and assistance to passengers in the event of denied boarding and of cancellation or long delays of flights ECC No 295/91 [2004] OJ L 46. Article 8 allows to obtain the "full cost of the ticket at the price at which it was bought, for the part or parts of the journey not made, and for the part or parts already made if the flight is no longer serving any purpose in relation to the passenger's original travel plan." See also Council Directive 85/374/EEC of 25 July 1985 on the approximation of the laws, regulations and administrative provisions of the Member States concerning liability for defective products (85/374/EEC).

126 ECHR, Art. 41.

127 Geler-Noch and Kirchner (2012), p. 25 (citing Peters (2003), p. 193).
} 
legislators could prevent indirect purchasers from seeking full compensation, and empower only direct purchasers. However, it is also true that setting the threshold at such a broad level allows for a better development of full compensation. Even if reaching and compensating victims will be impossible in some cases, the potential of indirect purchasers' claims will always bring new thoughts, perspectives and ideas to the litigation landscape - both in competition law and in other types of litigation. In addition, the right of vulnerable victims to claim compensation will be respected, even if it cannot be exercised in all cases. For these reasons, the inclusion of the indirect purchaser rule should be welcomed.

\section{Conclusion}

The EU reform on facilitating private antitrust claims is driven by the objective of ensuring full compensation to every economic victim of anticompetitive behaviour. This objective requires the implementation of a very effective compensation scheme: both direct and indirect purchasers should be entitled to obtain full award for the harm caused, including the actual damages, loss of profit and interest. Despite its grand objectives, the EU's private antitrust reform is bound to fall short of its stated goal of fully compensating every victim.

The reform is framed such that neither direct purchasers nor indirect purchasers can effectively exercise their right to claim and obtain full compensation. The standing for indirect purchasers undermines the incentives for direct purchasers, because defendants are allowed to invoke the passing-on defence. Despite the new right for indirect purchasers to seek compensation, they are prevented from enforcing their right: there are no provisions regarding collective actions in the Directive. In this regard, the Recommendation does not seem very helpful: it is a non-binding document and the proposed measures significantly diminish the chances for antitrust collective actions to ever be brought. As a result, the chances for indirect purchasers (and for victims with small claims) to obtain recovery depends on whether they are situated in a country with favourable rules regarding collective redress schemes; more particularly, whether opt-out schemes and assertive funding tools are allowed.

Another viewpoint is that the private antitrust reform is principally aimed at preserving robust public enforcement. By granting absolute protection to leniency statements and settlement submissions, the incentive to bring claims on behalf of victims with small claims is significantly diminished. To make matters worse, stand-alone actions are highly unlikely to be brought, as the EU reform lacks assertive provisions on funding and standing. Therefore, by preventing stand-alone actions and limiting followon actions, the EU simultaneously prevents private enforcement not only from effectively compensating victims, but also from remedying the public enforcement's shortcomings, such as a low detection rate. Without the contribution of private enforcement to the detection of antitrust violations, a large majority of infringements are bound to remain undetected, and many victims will remain uncompensated.

The rationale of full compensation in comparison with deterrence-based remedies has also been analysed. It was found that the enforcement of full compensation 
inevitably requires overstepping the bounds of the EU compensation regime. First, multiple damages are necessary to ensure full compensation standards (including actual loss and expected loss) and to compensate for the high case-related costs in optin actions. Second, broad discovery rules are vital for ensuring success in certifying collective actions. Third, reaching all types of victims requires a combination of optout schemes and forceful funding tools. In conclusion, the EU's compensation regime has more of a need for deterrence remedies than the US deterrence-oriented system, which forbids indirect purchaser litigation. Despite this, the EU is inclined to employ the conservative approach to achieve full compensation.

Open Access This article is distributed under the terms of the Creative Commons Attribution 4.0 International License (http://creativecommons.org/licenses/by/4.0/), which permits unrestricted use, distribution, and reproduction in any medium, provided you give appropriate credit to the original author(s) and the source, provide a link to the Creative Commons license, and indicate if changes were made.

\section{References}

BarentKrans (2015) Cartel damages claims in Europe

Boies D (2004) Courting justice: from NY Yankees $v$. Major League Baseball to Bush $v$. Gore, 1997-2000. Miramax, 1st edn

Buccirossi P et al (2012) Collective redress in antitrust. A study for the European Parliament's Committee on Economic and Monetary Affairs. http://www.europarl.europa.eu/document/activities/cont/ 201206/20120613ATT46782/20120613ATT46782EN.pdf. Accessed 12 June 2017

Büyüksagis E (2015) Standing and passing-on in the new EU Directive on antitrust damages actions. Swiss Rev Bus Law 87(1):18-30

Carmeliet T (2011-2012) How lenient is the European leniency system? An overview of current (dis)incentives to blow the whistle. Jura Falconis 48(3):463-512

Cavanagh ED (2010) The private antitrust remedy: lessons from the American experience. Loy Law J 41:629-649

Combe E, Monnier-Schlumberger C (2009) Les amendes contre les cartels: La Commission Européenne en fait-elle trop? Concurrences 4:41-50

Consumer Financial Protection Bureau (2015) Arbitration study: report to congress pursuant to DoddFrank Wall Street Reform and Consumer Protection Act $\S 1028(\mathrm{~A})$. http://files.consumerfinance. gov/f/201503_cfpb_arbitration-study-report-to-congress-2015.pdf. Accessed 12 June 2017

Crane DA (2010) Optimizing private antitrust enforcement. Vanderbilt Law Rev 63:675-723

Davis JP, Lande RH (2008) Benefits from private antitrust enforcement: an analysis of forty cases. Univ San Franc Law Rev 42:879-918

Drexl J (2015) Consumer actions after the adoption of the EU Directive on damage claims for competition law infringements. Max Planck Institute for Innovation and Competition, Research Paper No. 15-10. http://ssrn.com/abstract=2689521. Accessed 12 June 2017

Driessen-Reilly M (2015) Private damages in EU competition law and arbitration: a changing landscape. Arbitr Int 31(4):567-587

Duns et al (2016) Comparative competition law. Edward Elgar Pub, Cheltenham

Eisenberg T, Miller G (2010) Attorneys' fees and expenses in class action settlements: 1993-2008. J Empir Legal Stud 7(2):248-281

European Commission (2015) The damages directive-towards more effective enforcement of the EU competition rules. Competition Policy Brief, Brussels. http://ec.europa.eu/competition/publications/ cpb/2015/001_en.pdf. Accessed 12 June 2017

European Commission (2016) Directive on antitrust damages actions-competition. http://ec.europa.eu/ competition/antitrust/actionsdamages/directive_en.html. Accessed 28 Dec 2016

Fitzpatrick BT (2010a) Do class action lawyers make too little? Univ Pa Law Rev 158:2043-2083

Fitzpatrick BT (2010b) An empirical study of class action settlements and their fee awards. J Empir Legal Stud 7(4):811-846 
Fitzpatrick BT, Gilbert RC (2015) An empirical look at compensation in consumer class actions. N Y Univ J Law Bus 11(4):707-792

Friedman GB, Gilles ME (2006) Exploding the class action agency costs myth: the social utility of entrepreneurial lawyers. Univ Pa Law Rev 155:103-164

Geler-Noch K, Kirchner S (2012) Compensation under the European Convention on Human Rights for expropriations enforced prior to the applicability of the convention. Jurisprudence 19(1):21-29

Günsberg P (2015) Criminalizing business cartels in Europe-a comparative perspective. Doctoral dissertation, University of Helsinki. https://helda.helsinki.fi/handle/10138/154265. Accessed 12 June 2017

Han et al (2008) The overcharge as a measure for antitrust damages. Amsterdam Center for Law \& Economics, Working Paper No. 2008-08. https://papers.ssrn.com/sol3/papers.cfm?abstract_id= 1387096. Accessed 2 May 2017

Harrison F, Jones K (2014) Criminal sanctions: an overview of EU and national case law. e-Competitions. http://awa2015.concurrences.com/articles-awards/business-articles-awards/article/criminal-sanctionsan-overview-of-eu-and-national-case-law. Accessed 12 June 2017

Hensler D et al (2000) Class action dilemmas: pursuing public goals for private gains. RAND Corporation, 1st edn

Hodges C (2008) The reform of class and representative actions in European legal systems: a new framework for collective redress in Europe. Hart Publishing, Oxford

Hodges C (2014) Collective redress: a breakthrough or a damp sqibb? J Consum Policy 37(1):67-89

Howells G, Micklitz HW (2009) Guidelines for consumer organisations on enforcement and collective redress. Consumer Law Enforcement Forum Project. http://www.cojef-project.eu/IMG/pdf/d_ CLEFfinalguidelines_76647.pdf. Accessed 12 June 2017

Hüschelrath K, Laitenberger U, Smuda F (2012) Cartel enforcement in the European Union: determinants of the duration of investigations. Centre for European Economic Research, Discussion Paper No. 12-071. http://ftp.zew.de/pub/zew-docs/dp/dp12071.pdf. Accessed 12 June 2017

Italianer A (2013) Fighting cartels in Europe and the US: different systems, common goals. Annual Conference of the International Bar Association, Boston. http://ec.europa.eu/competition/speeches/ text/sp2013_09_en.pdf. Accessed 12 June 2017

Juška ̌̌ (2016) The impact of contingency fees on collective antitrust actions: experiments from Lithuania and Poland. Rev Cent East Eur Law 41(3-4):368-395

Kuijpers M et al (2017) Actions for damages in the Netherlands, the United Kingdom, and Germany. J Eur Compet Law Pract 8(1):47-65

Kutin B (2011) Consumer movement in central and Eastern Europe. Consumatori, Dirittei Mercato, pp 102-110. http://www.consumatoridirittimercato.it/wp-content/uploads/2012/12/2011-02consumer-movement-in-central-and-eastern-europe-n543470.pdf. Accessed 12 June 2017

Lande RH (1993) Are antitrust "treble" damages really single damages? Ohio St Law J 54:115-174

Lande RH (2016) Class warfare: why antitrust class actions are essential for compensation and deterrence. Antitrust 30(2):81-85

Maier-Rigaud FP (2014) Toward a European Directive on damages actions. J Comper Law Econ 10(2):341-360

Mariniello M (2013) Do European fines deter price fixing? Bruegel Policy Rev 4. http://bruegel.org/ wpcontent/uploads/imported/publications/Do_European_Union_fines_deter_price-fixing-_ English_.pdf. Accessed 12 June 2017

Mayer Brown (2013) Do class actions benefit class members? An empirical analysis of class actions. https://www.mayerbrown.com/files/uploads/Documents/PDFs/2013/December/

DoClassActionsBenefitClassMembers.pdf. Accessed 12 June 2017

Murray RC, Richman BD (2007) Rebuilding Illinois Brick: a functionalist approach to the indirect purchaser rule. South Calif Law Rev 81:69-110

Nagy CI (2013) Comparative collective redress from a law and economics perspective: without risk there is no reward! Columbia J Eur Law 19(3):469-498

Oxera (2014) Passing game: the ongoing debate about pass-on in damages actions. http://www.oxera. com/Latest-Thinking/Agenda/2014/Passing-game-the-ongoing-debate-about-pass-on-in-d.aspx. Accessed 12 June 2017

Page WH (1985) The scope of liability for antitrust violations. Stanf Law Rev 37(6):1445-1512

Peters A (2003) Einführung in die Europäische Menschenrechtskonvention, 1st edn. Verlag C.H. Beck, Munich 
Peyer S (2015) Compensation and the Damages Directive. Centre for Competition Policy, Working Paper 15-10. https://papers.ssrn.com/sol3/Papers.cfm?abstract_id=2654187. Accessed 12 June 2017

Posner RA (2001) Antitrust law, 2nd edn. University of Chicago Press, Chicago

Renda A et al (2008) Making antitrust damages actions more effective in the EU: welfare impact and potential scenarios. Centre for European Policy Studies, Brussels. http://ec.europa.eu/competition/ antitrust/actionsdamages/files_white_paper/impact_study.pdf. Accessed 12 June 2017

Rubenstein WB, Pace NM (2008) How transparent are class action outcomes? Empirical research on the availability of class action claims data. RAND Institute for Civil Justice, WR-599-ICJ. http:// billrubenstein.com/Downloads/RAND\%20Working\%20Paper.pdf. Accessed 12 June 2017

Schwartz WF (1980) An overview of the economic of antitrust enforcement. Georget Law J 68:1075-1102

Slotboom M (2013) Individual liability for cartel infringements in the EU: an increasingly dangerous minefield. Kluwer Competition Law Blog. http://kluwercompetitionlawblog.com/2013/04/25/ individual-liability-for-cartel-infringements-in-the-eu-an-increasingly-dangerous-minefield/. Accessed 12 June 2017

Smuda F (2012) Cartel overcharges and the deterrent effect of EU competition law. Centre for European Economic Research, No. 12-050. http://ftp.zew.de/pub/zew-docs/dp/dp12050.pdf. Accessed 12 June 2017

Sourcebook of Criminal Justice Statistics Online (2004) Antitrust cases filed in district courts. University of Albany, Albany. http://www.albany.edu/sourcebook/pdf/t5412004.pdf. Accessed 12 June 2017

UFC-Que Choisir (2011) Consultation de la Commission Europenne sur les recours collectifs contribution de L UFC-Choisir. http://ec.europa.eu/competition/consultations/2011_collective_ redress/ufc_que_choisir_de_rennes_fr.pdf. Accessed 12 June 2017

Whelan P (2012) Criminal sanctions: an overview of EU and national case law. e-Competitions. https:// www.concurrences.com/en/bulletin/special-issues/Criminal-sanctions/Criminal-sanctions-Anoverview-of. Accessed 12 June 2017

WHICH (2011) Public consultation: towards a coherent European approach to collective redress. http:// ec.europa.eu/competition/consultations/2011_collective_redress/which_en.pdf. Accessed 12 June 2017

Wils WPJ (2009) The relationship between public antitrust enforcement and private actions for damages. World Compet 32(1):3-26

Wils WPJ (2013) Ten years of Regulation 1/2003-a retrospective. J Eur Compet Law Pract 4(4):293-301

Živković P (2017) Antitrust arbitration in Europe (Part I): improving private enforcement by removing procedural and evidential barriers in arbitration. Kluwer Arbitration Blog. http:// kluwerarbitrationblog.com/2017/03/17/booked-microsoft-v-sony-arbitrating-antitrust-damagesclaims/. Accessed 2 May 2017 